J. Clin. Chem. Clin. Biochem.

Vol. 20, 1982, pp. 773-785.

\title{
Zur Bestimmung der katalytischen Aktivität der Lipase mit dem kontinuierlichen titrimetrischen Test
}

Von M. Hockeborn und W. Rick

Institut für Klinische Chemie und Laboratoriumsdiagnostik der Universität Düsseldorf

(Eingegangen am 15. Oktober 1981/7. Januar 1982)

Zusammenfassung: Da vorgeschlagen wurde, das kontinuierliche titrimetrische Verfahren zur Bestimmung von Lipase im Serum zu normen, wird über Vergleichsuntersuchungen mit Triolein und Olivenöl als Substrat berichtet. Für Triolein werden bezüglich pH-Optimum, Konzentrationen von Substrat sowie Glykocholat u.a. optimale Bedingungen ausgearbeitet. Die Ergebnisse entsprechen den früher mit Olivenöl als Substrat gewonnenen Resultaten. Erfahrungen hinsichtlich der Qualität der seit 1966 verwendeten Reagentien-Chargen werden mitgeteilt. Die weitere Diskussion betrifft die bei der Methodik auftretenden Probleme, insbesondere die mangelhafte Charakterisierung und Reinheit der Gallensäurepräparate und ihre Auswirkung auf die Testbedingungen. Eine kritische Betrachtung zeigt, daß Zweipunktteste und Modifikationen des kontinuierlichen titrimetrischen Verfahrens nicht zu zuverlässigen Resultaten führen können. Die ungeprüfte Übernahme von Daten aus det Literatur wird am Beispiel der Hämolyse und ihrer Auswirkung auf die Lipaseaktivität erläutert. Ferner wird auf die erforderliche Empfindlichkeit der Meßgeräte, auf Fehler bei der praktischen Durchfuihrung sowie auf die unkritische Auswertung und Interpretation von Analysendaten eingegangen. Erste Versuche mit Zusatz von Colipase werden beschrieben. Die Diskussion umfaßt auch die Frage, ob der Cofaktor routinemäßig dem Test zugesetzt werden soll und ob die Lipoproteinlipase quantitativ gehemmt werden kann.

Aufgrund des hohen apparativen und zeitlichen Aufwands ist das kontinuierliche titrimetrische Verfahren für ungezielt angeordnete Serienuntersuchungen zweifellos nicht geeignet. Andererseits war es bisher nicht möglich, einfachere Methoden zu entwickeln, die reproduzierbar zu quantitativen Ergebnissen führen.

\section{Determination of lipase by continuous titration}

Summary: Development of a standardized procedure for the titrimetric assay of lipase has been suggested. Comparative studies with triolein und olive oil were therefore undertaken. Optimal conditions, such as $\mathrm{pH}$, substrate and glycocholate concentrations, etc. were determined for the assay with triolein. The results agree with those obtained earlier with olive oil as substrate. Experience with the quality of various reagents used since 1966 is reported. Problems of methodology are then discussed, especially the incomplete characterization and purity of the bile acid preparations, and their effects on the test conditions. A critical analysis shows that two point tests with modifications of the continuous titration cannot give reliable results. Haemolysis and its effect on catalytic activity of lipase are used to illuistrate the consequences of the uncritical acceptance of data from the literature. Furthermore, the required sensitivity of the analytical equipment, operational errors, and the uncritical evaluation and interpretation of analytical data are discussed. The first experiments to be performed with the addition of colipase are described, and the question of whether this coffactor should be used routinely for test purposes is considered. The problem of whether lipoproteinlipase can be quantitatively inhibited is discussed. In view of the outlay on apparatus and the - time required for the assay, continuous titration is definitely not suitable for routine screening purposes. On the other hand, simpler methods that give reproducible quantitative results have not yet been developed.

\section{Einführung}

Zur Pankreaslipase (Triacylglycerol acyl hydrolase, EC 3.1.1.3) sind in den letzten Jahren mehrere Übersichtsarbeiten erschienen (1-5). Das große Interesse der Grundlagenforschung an diesem Enzym beruht u.a. darauf, daß Lipase ihre Wirkung an Grenzflächen ent- faltet. Gerade diese Eigenschaft bedingt aber andererseits die vielschichtige Problematik bei der Messung der katalytischen Aktivität des Enzyms. Daher besteht bei der Lipase zwischen den Erkenntnissen der Biochemie und den diagnostischen Anwendungsmöglichkeiten eine besonders große Diskrepanz. 
Wie von zahlreichen anderen Meßverfahren - z.B. dem Radioimmunoassay - her bekannt ist, lassen sich die an reinen Substanzen gewonnenen Befunde nicht ohne weiteres auf so komplexe Gemische wie Serum u.ä. übertragen. Die z.T. erheblichen Widersprüche der Ergebnisse in verschiedenen Publikationen über Lipase sind sicher mit dadurch verursacht, daß die an gereinigten Proteinen ermittelten Meßbedingungen ohne weitere Prüfung zur Analyse von Körperflüssigkeiten verwendet werden. Ferner können die Diskrepanzen zwischen den Befunden verschiedener Arbeitsgruppen darauf beruhen, daß die erforderlichen Substanzen z.T. nicht ausreichend definiert bzw. analysiert oder nicht in reproduzierbarer Qualität im Handel erhältlich sind. Weitere Probleme entstehen dadurch, daß an die Stabilität und das Auflösungsvermögen der verwendeten Meß- und Regelgeräte immer höhere Anforderungen gestellt werden. Bei der Vielzahl der Angebote, die eine unterschiedliche Qualität aufweisen, ist es dem Benutzer aber kaum noch möglich, mit allen Gerätekombinationen eigene Erfahrungen zu sammeln. So kann es durchaus sein, daß er für seine speziellen Àrbeiten nicht das am besten geeignete Gerät benutzt. Schließlich ist darauf hinzuweisen, daß die technische Durchführung schwieriger Analysenverfahren häufig aufgrund mangelnder eigener experimenteller Erfahrung nicht genügend kritisch betrachtet wird.

Da der Vorschlag gemacht wurde (6), den 1969 (7) bzw. 1976 (8) beschriebenen kontinuierlichen titrimetrischen Test zur Bestimmung der Lipase zu normen, werden hier die oben angeschnittenen Probleme in Bezug auf dieses Bestimmungsverfahren besprochen. Außerdem werden Ansatzpunkte zur Erhöhung der Spezifität durch Zusatz von Colipase in den Testansatz diskutieṛt.

\footnotetext{
Material

Reagentien

$\mathrm{Zu}$ den vorliegenden Untersuchungen wurden die bereits 1969 bei der Beschreibung des kontinuierlichen titrimetrischen Tests mit Olivenöl als Substrat (7) aufgeführten Reagentien benutzt. Zusätzlich wurden verwendet:

Triolein rein, etwa 95\%, Serva Bestell-Nr. 37085.

Triolein, A grade, über 90\%, Calbiochem Bestell-Nr. 6450.

Trilinolein, etwa 99\%, Sigma Bestell-Nr. T-3252.

Glykocholsäure purum, etwa 95\%, Fluka Bestell-Nr. 50540, z.Z. Charge 19579.

Glykocholsäure, Natriumsalz, Calbiochem Bestell-Nr. 360512 , z.Z. Charge 810044.

Colipase aus Schweinepankreas (Lyophilisat). Das Präparat wurde uns freundlicherweise von Herrn Prof. Dr. H. U. Bergmeyer und Herrn Dr. J. Ziegenhorn zur Verfügung gestẹllt.

\section{Lösungen}

Die Lösungen entsprachen den Angaben von 1969 (7). Bei der Zubereitung der Substratemulsionen wurden analog zu Olivenöl auch Triolein bzw. Trilinolein verwendet.
}

\section{Probenmaterial}

Bei den verwendeten Proben handelte es sich um:

Seren von Gesunden,

Seren von Patienten mit akuten oder chronischen Pankreaserkrankungen,

Seren, die etwa 10 Minuten nach i.v. Injektion von 5000 I.E. Heparin von Gesunden gewonnen wurden,

Sammelserum, in dem die Pankreaslipase durch zweistündige Inkubation bei $56^{\circ} \mathrm{C}$ vollständig inaktiviẹt worden war.

\section{Methodik}

Meßanordnung und Methodik entspiachen den Angaben voñ 1969 (7).

\section{Ergebnisse}

Vergleiche żwischen Triolein und Olivenöl als Substrat

Für die Bestimmung der Lipase im kontinuierlichen titrimetrischen Test wựde ursprünglich Olivenöl verwendet $(7,9)$. Da dieses Naturprodukt auch im DAB nicht sehr eingehend definiert wird, prüften wir jede neüe Charge durch Vergleichsuntersuchungen auf ihre Eignung zur Messung der katalytischen Aktivität der Lipase. Dabei fiel auf, daß das 1969 erhältliche, nach DAB 7 châarakterisierte Präparat in Anwesenheit der dãmals üblicherwèise verwendeten Glykocholatkonzentration weniger als die Hälfte der Sollaktivität ergab. Es lạg nahe, verșchiedene Qualitäten von Olivenöl und von Triolein, einem besser definierten Subștrat, zu prüfen. Im Gegensatż zu einer 1968 benutžten Triolein-Charge, die offenbar Hemmstoffe 0 .ä. für Lipase enthielt (7), erwiesen sich die 1969 untersuchten Präparate der Firmen Calbiochem und Serva als geeignet, sie ergaben im Standardtest (7) die gleichen katalytischen Aktivitäten wie die bisher benutzten Olivenöl-Emulsionen. Wegen der außerordentlich komplizierten Reaktionsabläufe bei der Hydrolyse wasserunlöslicher Substrate durch Lipase prüften wir, ob die 1969 beschriebenen Testbedingungen auch für Triolein als Substrat gelten.

\section{pH-Optimum}

Zur Ermittlung des pH-Optimums wurde Serum eines Patienten mit akuter Pankreatitis in den kontinuièrlichen Test eingesetzt und der pH-Wert der Hydrolyse des Substrats variiert. Es ergab sich entsprechend den Versuchen mit Olivenöl ein pH-Optimum zwischen 8,5 und 9,0 (Abb. 1).

\section{Substratkonzentration}

Weiterhin wurde die Abhängigkeit dẹr Reaktionsgeschwindigkeit von der Substratkonzentration mit gereinigter Pankkreaslipase geprüft. Die Ergebnisse sind in der Auswertung nach Hofstee (10) in Abbildung 2 dargestellt. Für die Michaelis-Konstante der Hydrolyse von Triolein durch Lipase bei pH 8,6 und $25^{\circ} \mathrm{C}$ ergab sich 
ein Wert von 3,8 $\mathrm{mmol} / 1$. Die Maximalgeschwindigkeit betrug $V=8450 \mathrm{U} / 1$; bei den im Abschnitt "Testansatz“ (7) beschriebenen Konzentrationen wurden $99 \%$ der maximalen Geschwindigkeit gemessen. Diese Ergebnisse stimmen mit den unter Verwendung von Olivenöl für Serum ermittelten Daten $\left(K_{\mathrm{m}}=3,4 \mathrm{~g} / 1 ; \nu=98 \%\right.$ von $V$ (7) gut überein.

\section{Substratemulsion}

Die Triolein-Emulsion in Gummi arabicum-Lösung wurde unterschiedlich lange homogenisiert; zwischen 3 und 10 Minuten ergab sich - entsprechend den früheren Befunden - keine Änderung der Hydrolysegeschwindigkeit des Substrats.

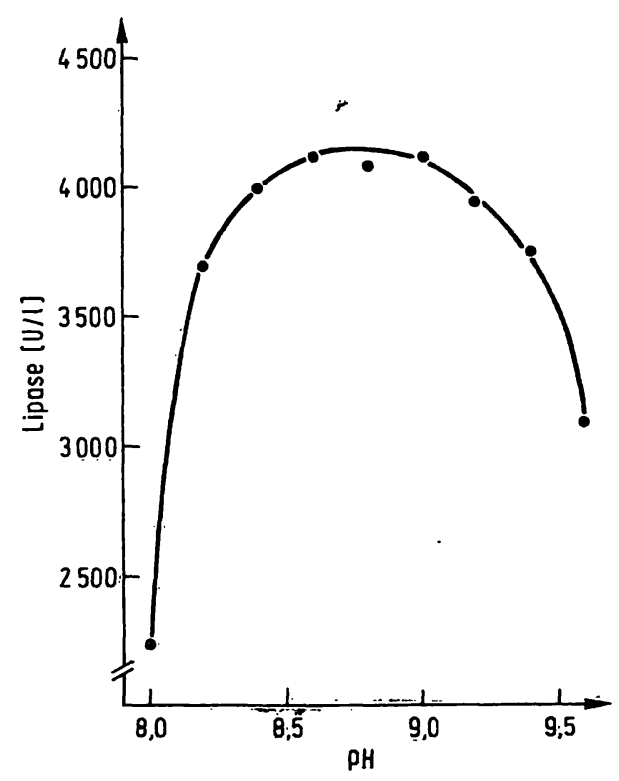

Abb. 1. Kontinuierlicher titrimetrischer Test mit Triolein als Substrat. Ábhängigkeit der kataly tischen Aktivität von Lipase im Serum vom $\mathrm{pH}$-Wert des Testansatżes.

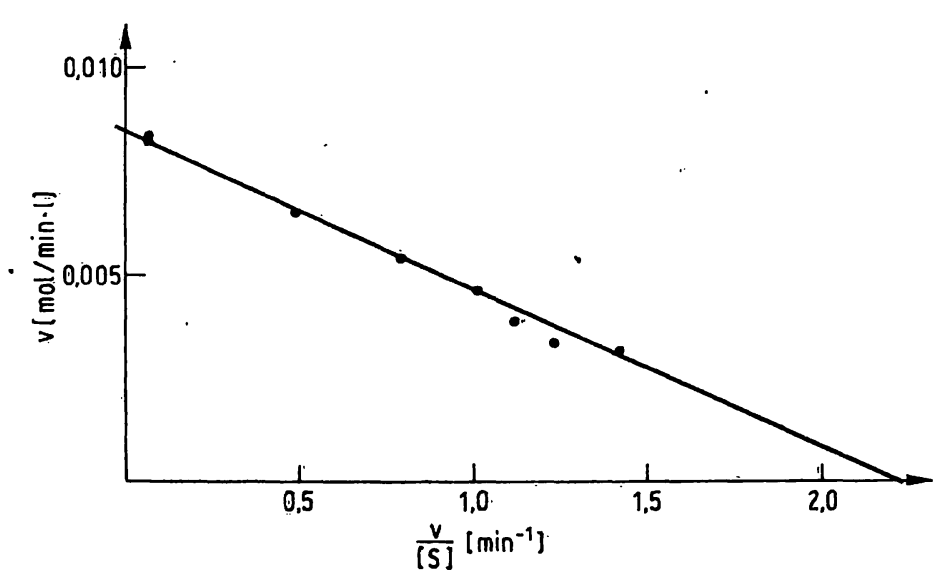

Abb. 2. Kontinuierlicher titrimetrischer Test mit Triolein als Substrat. Abhängigkeit der katalytischen Aktivität gereinigter Pankreaslipase von der Substratkonzentration. Auftragung nach Hofstee; $\mathrm{v}=\mathrm{mol} / \mathrm{min} \cdot \mathrm{l} ;[\mathrm{S}]=\mathrm{mol} / \mathrm{l}$.

\section{Einfluß von $\mathrm{Na}$-Glykocholat}

Auch die Konzentration von Na-Glykocholat im Testansatz wurde variiert. Wie bereits 1969 beschrieben (7), zeigte sich eine wechselseitige Abhängigkeit von Probevolumen im Test und Glykocholatkonzentration (Abb. 3): Je mehr Serum in den Test eingesetzt wird, desto geringer ist die relative Aktivierung durch Glykocholat, desto eher wird die maximale Aktivität gemessen und um so schneller wird die Hemmwirkung höherer Glykocholatkonzentrationen beobachtet. Je geringer das Probevolumen, desto stärker ist die Aktivierung durch Glykocholat in Bezug auf den Ausgangswert und desto später setzt die Hemmung in Anwesenheit von höheren Konzentrationen der Gallensäure ein. Wiederum zeigten verschiedene Proben bezüglich des Hemmeffekts ein ganz individuelles Verhalten. Ebenso wie beim früher verwendeten Olivenöl betrug die optimale Konzentration der in den Test einzusetzenden Glykocholsäure bei der damals benutzten Charge $1,5 \mathrm{mmol} / 1$. Dies galt für alle eingesetzten Probevolumina, sowohl bei der Analyse von Seren als auch bei der Verwendung von gereinigter Pankreaslipase und Duodenalsaft. Bei Einsatz dieser optimalen $\mathrm{Na}$-Glykocholatkonzentration ergaben șämtliche Untersuchungen an Seren von Gesunden, Patienten mit akuter Pankreatitis und reinen Präparaten von Pankreaslipase mit Olivenöl und Triolein als Substrat innerhalb des Meßfehlers die gleichen katalytischen Aktivitäten.

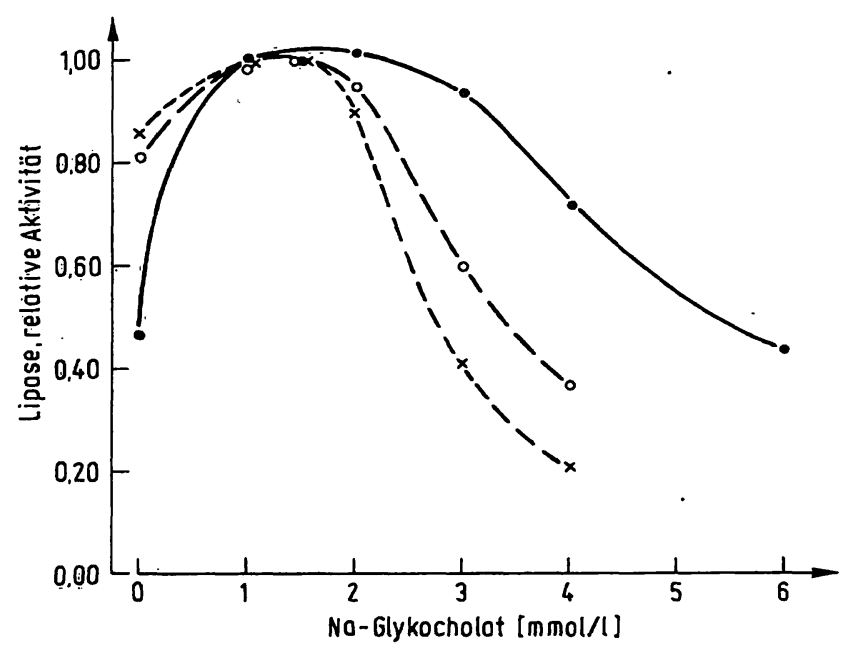

Abb. 3. Kontinuierlicher titrimetrischer Test mit Triolein als Substrat. Abhängigkeit der katalytischen Aktivität von der Na-Glykocholatkonzentration bei Einsatz unterschiedlicher Probevolumina.

$-100 \mu \mathrm{l}$ Serum J. im Test

$0--0500 \mu$ l Serum N. im Test $x--x 1,0 \mathrm{ml}$ Serum R. im Test

\section{Einfluß von Calcium- und Natriumchlorid}

Wir prüften weiterhin die katalytische Aktivität von Lipase in Abhängigkeit von zusätzlich in den Testansatz gegebenem Calcium- bzw. Natriumchlorid und fanden das bereits mit Olivenöl als Substrat beschriebene Ver- 
halten (7): Zusatz von $\mathrm{Ca}^{++}$führte in Abwesenheit von Gallensäuren nicht zu einer Aktivierung des Enzyms; bei höheren Konzentrationen (ab $10 \mathrm{mmol} / \mathrm{l}$ ) wurde eine geringfügige Hemmung beobachtet. Bei gleichzeitiger Zugabe von Glykocholat in den Test fand sich eine deutliche Hemmung der Lipase und eine sichtbare Entmischung der Substratemulsion. Der Zusatz von Natriumchlorid ohne Gallensäuren im Test führte nicht zu einer Änderung der katalytischen Aktivität des Enzyms, während im Testansatz mit Glykocholat wiederum eine ausgeprägte Hemmung nachweisbar war.

\section{Probevolumen im Test}

Ebenso wie bei Verwendung von Olivenöl ergab sich mit Triolein als Substrat ein geradliniger Zusammenhang zwischen Probevolumen und gemessener katalytischer Aktivität des Enzyms bis zum Einsatz von $1,0 \mathrm{ml}$ Serum (Abb. 4). Von einem hochaktiven Serum (5650 U/1) wurden 20 bis $100 \mu \mathrm{l}$ analysiert; auch hier war die Proportionalität zum Substratumsatz vorhanden (Abb. 5).

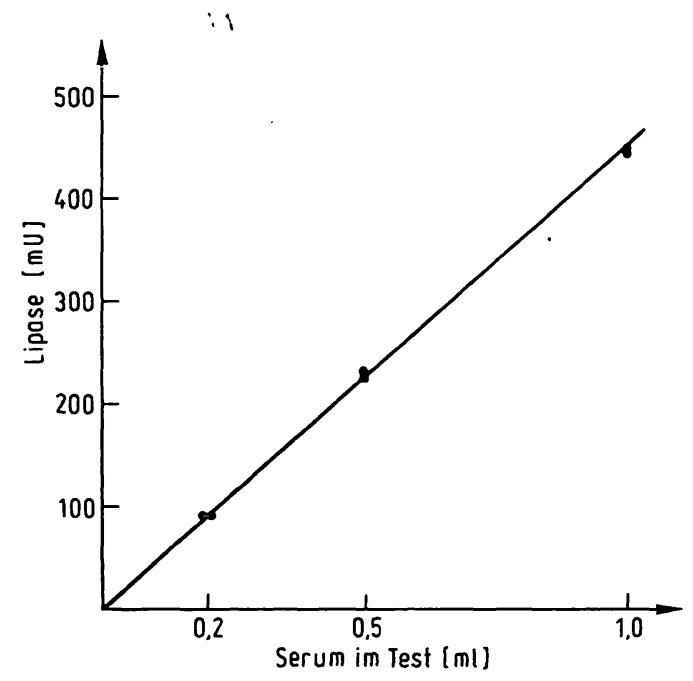

Abb. 4. Kontinuierlicher titrimetrischer Test mit Triolein als Substrat. Abhängigkeit der katalytischen Aktivität vom eingesetzten Serumvolumen. Serum $\mathrm{Ri}$. im Test, kataly tische Aktivität $445 \mathrm{U} / 1$.

Vergleich von Trilinolein und Triolein als Substrat

Das von Proelss \& Wright (11) als Substrat vorgeschlagene Trilinolein wird durch Normalserum, Serum von Patienten mit akuter Pankreatitis, gereinigter Pankreaslipase und von Postheparinserum mit gleicher Geschwindigkeit umgesetzt wie Triolein (12). Wegen der außerordentlich hohen Preisdifferenz haben wir uns für die Verwendung von Triolein entschieden.

\section{Zur Qualität verschiedener Reagentienchargen}

\section{Triolein}

Aufgrund der oben beschriebenen Ergebnisse verwendeten wir seit August 1969 für unsere Untersuchungen Triolein, etwa 95\%, der Firma Serva. In Parallelansätzen

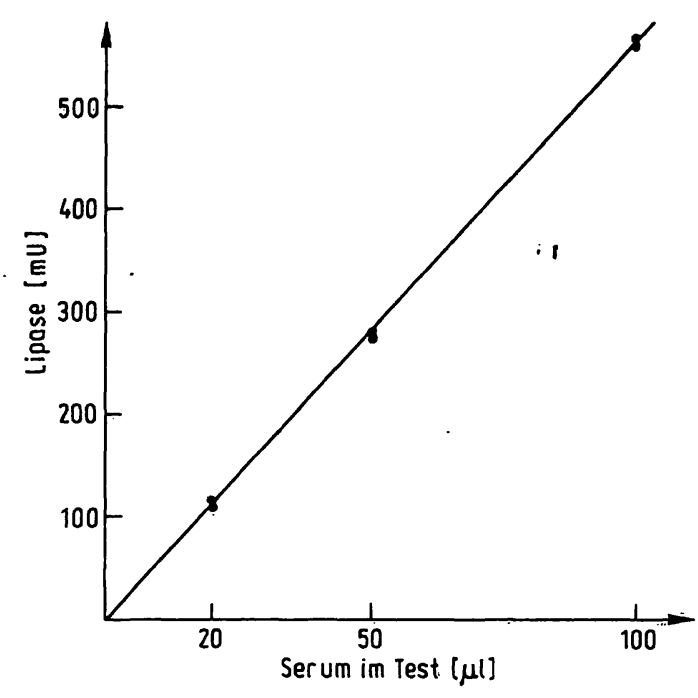

Abb. 5. Kontinuierlicher titrimetrischer Test mit Triolein als Substrat. Abhängigkeit der katalytischen Aktivität vom eingesetżten Serumvoolumen. Serum F. im Test, katalytische Aktivität $5650 \mathrm{U} / 1$.

erwiesen șich - mit einer einzigen Ausnahme im Jahre 1972 - alle geprüften Chargen als brauchbar. Um den Aufwand an Vergleichsuntersuchungen in vertretbar̈en Grenzen zu halten, bewahren wir eine größere Menge Öl der gleichen Charge bei +4 bis $+8^{\circ} \mathrm{C}$ auf und schützen die Substanz in der jeweils angebrochen Flasche durch erneutes Durchströmen mit $\mathrm{N}_{2}$ vor der Bildung von Peroxiden.

\section{Gummi arabicum}

Das zur Herstellung der Substratemulsion verwendete Gummi arabicum stellt keine genau definierte Substanz dar. Alle Versuche, es durch einen.anderen Emulgator zu ersetzen, schlugen insofern fehl, als niedrigere katalytische Aktivitäten im Vergleich zu Gummi arabicum gemessen wurden. Zwischen den benutzten Chargèn dieses Substratstabilisators fanden sich keine Unterschiede in den fự die Bestimmung der Lipase relevanten Eigenschaften. Es hat sich bewährt, die unlöslichen Partikel nicht durch das zeitaufwendige Absetzenlassen, sondern durch Abzentrifugieren zu entfernen.

\section{Glykocholsäure}

Ein besonderes Problem stellt die Reinheit der verfügbaren Gallensäuren dar. Mit den zwischen 1969 und 1979 von uns verwendeten Chargen Glykocholat lag das Optimum der katalytischen Aktivität der Lipase bei einer Endkonzentration von $1,5 \mathrm{mmol} / 1$. Die im Jahre 1980 bezogene Charge 19579 Glykocholsäure pürum (über 95\%) von Fluka hat offenbar eine andere Zusammensetzung, denn dieses Präparat führte in der angegebenen Konzentration bei den meisten Proben bereits żu einem deutlich geringeren Substratumsatz. In Abbildung 6 ist die Abhängigkeit der katalytiṣchen Aktivität der Lipase von der Konzentration an Glykocholat mit der gleichen Probe und Triolein-Emulsion - an eịịem Tag ausge- 
führt - für die frühere und die letztgenannte Charge dargestellt. Im Gegensatz zu unserer Mitteilung von 1969 (7) können bei Verwendung von Glykocholsäure (Fluka) der Charge 19579 nur $150 \mu \mathrm{l}$ einer Lösung von $75 \mathrm{mmol} / 1$, entsprechend einer Endkonzentration von $0,75 \mathrm{mmol} / \mathrm{l}$ in den Test eingesetzt werden. Das gleiche gilt für Glykocholsäure der Charge 810044 von Calbiochem. Leider ergaben Rückfragen bei der Herstellerfirma, daß eine ausreichende Charakterisierung der Gallensäure nicht vorliegt. Daher ist es notwendig, vor jeder Anwendung eines neuen Glykocholatpräparats die in Abbildung 3 und Tabelle 1 gezeigte Abhängigkeit der gemessenen Aktivität von der Glykocholatkonzentration an einer Reihe von Seren mit unterschiedlicher katalytischer Aktivität, die den Einsatz verschiedener Probevolumina ermöglichen, zu prüfen. Keineswegs genügt es, nur zwei an der gleichen Probe gewonnene Ergebnisse zu vergleichen, da jedes Serum bezüglich des Hemmeffekts durch hohe Glykocholatkonzentrationen einen individuellen Verlauf zeigt und somit bei Einsatz von nur einer Probe Hemmeffekte übersehen werden könnten. Zur Veranschaulichung sind in Tabelle 1 die für verschiedene Seren bei Einsatz von jeweils $1,0 \mathrm{ml}$ ermittelten Zusammenhänge zwischen katalytischer Aktivität der Lipase und Glykocholatkonzentration dargestellt. Außerdem ist für Forschungszwecke zu berücksichtigen, daß frische' und lange eingefrorene Proben (bei uns seit 1966) sich bezüglich der eintretenden Hemmung unterschiedlich verhal-

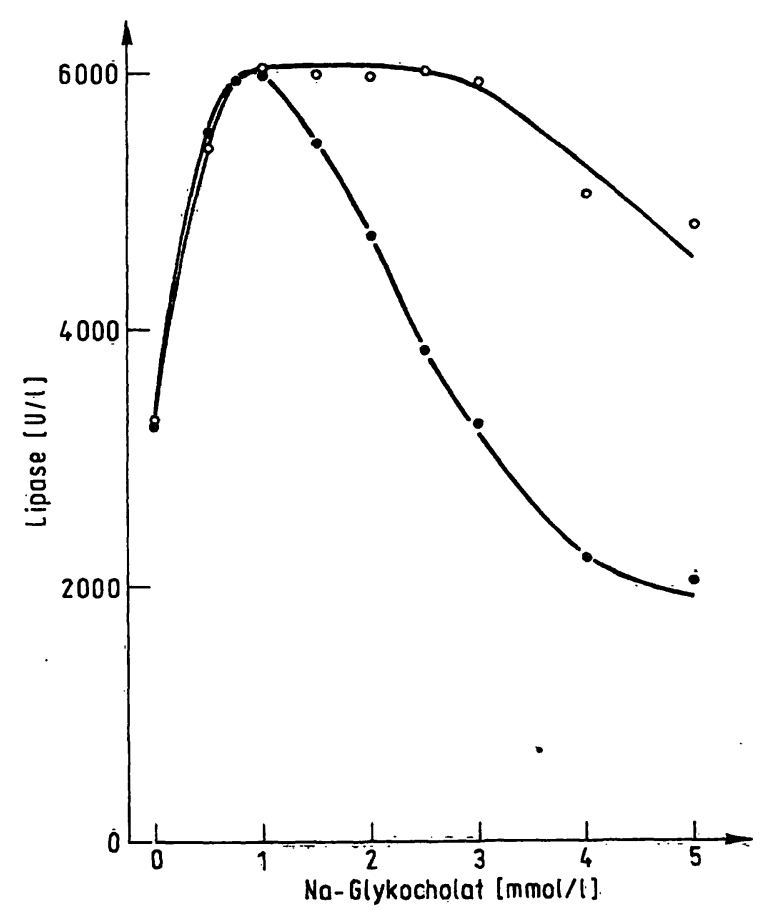

Abb. 6. Kontinuierlicher titrimetrischer Test mit Triolein als Substrat. Abhängigkeit der kataly tischen Aktivität von der Konzentration und der Charge des verwendeten Glykocholats. $100 \mu \mathrm{l}$ Serum im Test.

$\rightarrow$ Glykocholsäure purum, etwa: $95 \%$, Fluka Bestell-Nr. 50540, Charge 195.79

- - G Glykocholsäure purum, etwa $95 \%$, Fluka Bestell-Nr. 50540, 1969-1980 verwendete Chargen. ten, obgleich ihre katalytische Aktivität bei Einsatz der optimalen Gallensäurekonzentration unverändert erhalten ist. Bei durch Einfrieren unter $-20^{\circ} \mathrm{C}$ aufbewahrten Proben ist der Hemmeffekt durch hohe Na-Glykocholatkonzentrationen deutlicher. Systematische Untersuchungen liegen uns nicht vor, da wir die jahrelang konservierten Proben nicht mehr mit der gleichen Charge Glykocholsäure wie 1966 untersuchen konnten. Bei Verwendung der 1980 bezogenen Charge zeigte sich jedoch an verschiedenen eingefrorenen und frisch gewonnenen Proben der oben erwähnte Unterschied in Bezug auf die einsetzende Hemmwirkung.

Tab. 1. Kontinuierlicher titrimetrischer Test mit Triolein als Substrat.

Abhängigkeit der katalytischen Aktivität von der Glykocholatkonzentration (Fluka, Bestell-Nr. 50540, Charge 19579) an verschiedenen Proben bei Einsatz von jeweils $1,0 \mathrm{ml}$ Serum.

Die maximal gemessene Aktivität wurde gleich 100 gesetzt.

\begin{tabular}{llrrrrrr}
\hline Lipase & \multicolumn{8}{c}{ Endkonzentration an Na-Glykocholat (mmol/1) } \\
U/1 & 0,0, & 0,5 & 1,0 & 1,5 & 2,0 & 3,0 & 4,0 \\
\hline 685 & 92 & 100 & 99 & 79 & & & \\
555 & 92 & 100 & 89 & 76 & 63 & & \\
750 & 88 & 100 & 97 & 90 & 27 & & \\
405 & 82 & 99 & 100 & 100 & 100 & 86 & 70 \\
700 & 83 & 99 & 100 & 76 & 56 & & \\
685 & 82 & 100 & 99 & 99 & 99 & 90 & 61 \\
850 & 87 & 100 & 99 & 96 & 89 & & \\
435 & 88 & 100 & 95 & 68 & 30 & & \\
255 & 82 & 98 & 100 & 92 & 82 & & \\
755 & 85 & 100 & 99 & 100 & 97 & 96 & \\
\hline
\end{tabular}

\section{Einfluß von Hämolyse}

Da mehrfach ein Hemmeffekt von Hämoglobin auf die Lipase beschrieben wurde, soll hier auch zu dieser Frage Stellung genommen werden. Zur Gewinnung eines serumfreien Hämolysạts wurden Erythrocyten $5 \mathrm{mal}$ mit physiologischer $\mathrm{NaCl}$-Lösung gewaschen und anschlieüend in bidest. Wasser lysiert. Nach Abzentrifugieren der Stromata ergab sich eine Lösung mit einer Hämoglobinkonzentration von $90 \mathrm{~g} / 1$. Unterschiedliche Volumina dieser Lösung wurden in den kontinuierlichen titrimetrischen Test zusätzlich zu Serum mit erhöhter katalytischer Aktivität der Lipase eingesetzt. Die Ergebnisse sind in Tabelle 2 zusammengestellt. Bis zu einem Hämoglobinzusatz, der einer Hb-Konzentration in den verwendeten Seren von $45 \mathrm{~g} / \mathrm{l}$ entspricht, war eine Hemmung des Enzyms nicht nachweisbar.

\section{Zusatz von Colipase}

Serum von Patienten mit Pankreaserkrankungen im Test

Als Colipasen werden hitzestabile Cofaktoren der Lipase bezeichnet, die im Pankreas und Pankreassekret vorkommen und als Proteine charakterisiert werden konnten (Ubersicht bei Borgström et al. (4)). Trennt man Lipase und Colipase aus tierischem Pankreassekret durch Gel- 
Tab. 2. Kontinuierlicher titrimetrischer Test mit Triolein als Substrat. Einfluß von Hämoglobin auf die katalytische Aktivität.

\begin{tabular}{|c|c|c|c|}
\hline Serum & $\begin{array}{l}\text { Probevolumen } \\
\text { im Test }\end{array}$ & $\begin{array}{l}\text { Hämolysat } \\
90 \mathrm{~g} / 1 \mathrm{Hb} \text { im Test }\end{array}$ & $\begin{array}{l}\text { Lipase } \\
(U / 1)\end{array}$ \\
\hline \multirow[t]{3}{*}{ J. } & $100 \mu 1$ & ohne & $\begin{array}{l}3900 \\
3980\end{array}$ \\
\hline & & $200 \mu \mathrm{l}$ & $\begin{array}{l}4000 \\
4080\end{array}$ \\
\hline & & $500 \mu l$ & $\begin{array}{l}4000 \\
3940\end{array}$ \\
\hline \multirow[t]{3}{*}{ S. } & $1,0 \mathrm{ml}$ & ohne & $\begin{array}{l}490 \\
485\end{array}$ \\
\hline & & $200 \mu 1$ & $\begin{array}{l}475 \\
463\end{array}$ \\
\hline & & $500 \mu 1$ & $\begin{array}{l}475 \\
478\end{array}$ \\
\hline
\end{tabular}

filtration, so ist die katalytische Aktivität des Cofaktorfreien Enzyms in Abwesenheit von Gallensalzen je nach Spezies auf 60-80\% des Ausgangswertes mit nichtfraktioniertem Sekret herabgesetzt (13). Gibt man Gallensäuren in einer Menge in den Testansatz, die höher als die kritische micellare Konzentration ist, so wird die Lipase zunehmend gehemmt. Diese Inhibition kann durch steigende Mengen Colipase aufgehoben werden (13). Wir prüften an Seren mit unterschiedlicher katalytischer Aktivität, wie der Zusatz des Cofaktors die katalytische Aktivität des Enzyms beeinflußt; wenn die Glykocholatkonzentration im Testansatz variiert wird. Abbildung 7 zeigt die Ergebnisse, die mit einem Serum von geringer katalytischer Aktivität an Lipase eines 1966 beobachteten Patienten mit akuter Pankreatitis gewonnen wurden. Ohne Zusatz von Colipase ergibt Glykocholat eine Aktivierung um $13 \%$ der Ausgangsaktivität; es zeigt sich ein Aktivitätsoptimum zwischen einer Glykocholatkonzentration von 0,5-0,75 mimol/1. Setzt man dem Testansatz geringe Mengen Colipase zu, so wird das Aktivitätsoptimum breiter, es tritt jedoch keine zusätzliche Aktivierung der Lipase ein. Bei der höchsten eingesetzten Colipasekonzentration ( $30 \mathrm{mg} / \mathrm{l}$ ) ist ein Zusatz von $5 \mathrm{mmol} / 1$ Glykocholat möglich, ohne daß das Enzym gehemmt wird. Bei einem anderen, nicht eingefrorerien Serum werden im Prinzip ähnliche Kurvèn beobachtet (Abb. 8). Die optimale Glykocholatkonzentration liegt hier zwischen $0,5-2,0 \mathrm{mmol} / \mathrm{l}$. In Gegenwart von Cölipase in einer Endkonzentration von $3,0 \mathrm{mg} / \mathrm{l}$ fuhren auch $20 \mathrm{mmol} / 1$ Glykocholat niçht zu einèr Hemmung dès Enzyms. Können von Seren mit hoher katalytischer Aktivität nur geringe Volumina in den Test eingesetzt werden, so findet sich - wie bereits oben beschrieben durch die niedrige Proteinkonzentration ein stärker aktivierender Effekt des Glykocholats (Abb, 9 und 10); die maximale katalytische Aktivität wird in Abwešenheit von Cólipase żwischèn 0,5-1,0 mmol/1 bei Einsatz von eingefrorenem Serum bzw. 0,75-1,5 mmol/1 $\overline{\mathrm{Na}}$ Glykocholat bei frischem Serum im Ansatz erreicht. Colipase verbreitert dieșes Aktivitätsoptimum wiederum; schon bei einer Konzentration von $0,3 \mathrm{mg} / 1$ führt èine Erhöhung der Glykocholatkonzentration auf 5,0 mmol/1 nicht mehr zu einer Hemmung der katalytischen Aktivität.

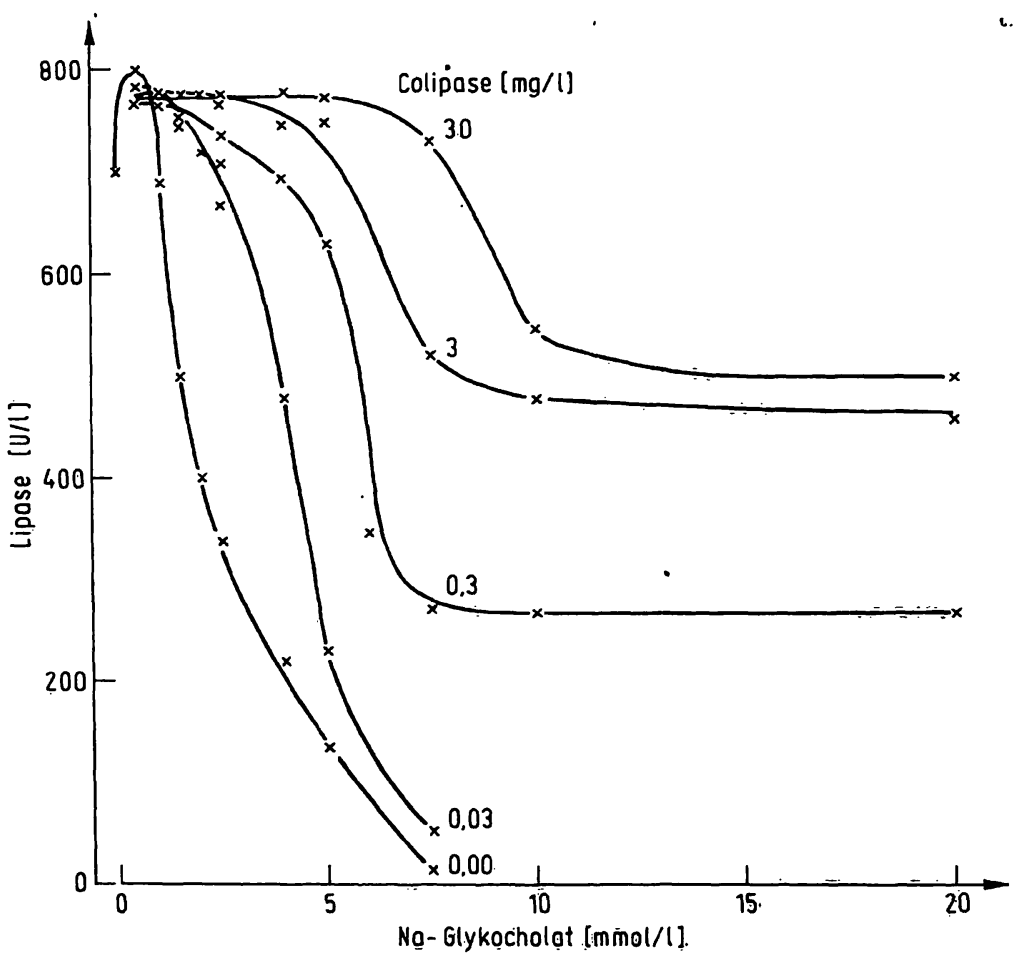

Abb. 7. Kontinuierlicher titrimetrischer Test mit Triolein als Substrat. Abhängigkeit der kataly tischen Aktivität von der Konzentration an Na-Glykocholat und an Colipase. 1,0 ml Serum M. (seit 1966 eingefroren) im Test. 


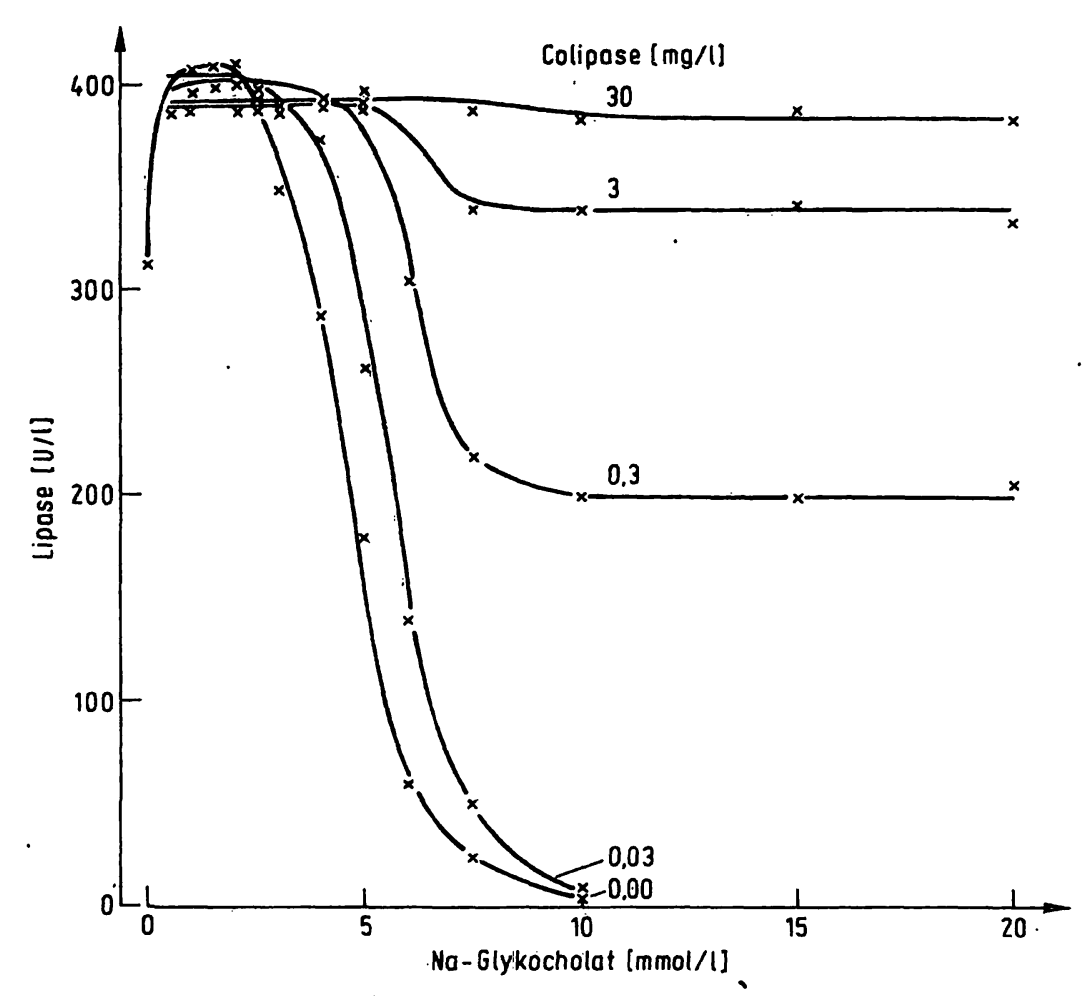

Abb. 8. Kontinuierlicher titrimetrischer Test mit Triolein als Substrat. Abhängigkeit der katalytischen Aktivität von der Konzentration an Na-Glykocholat und an Colipase. 1,0 ml Serum H. (nach Entnahme analysiert) im Test.

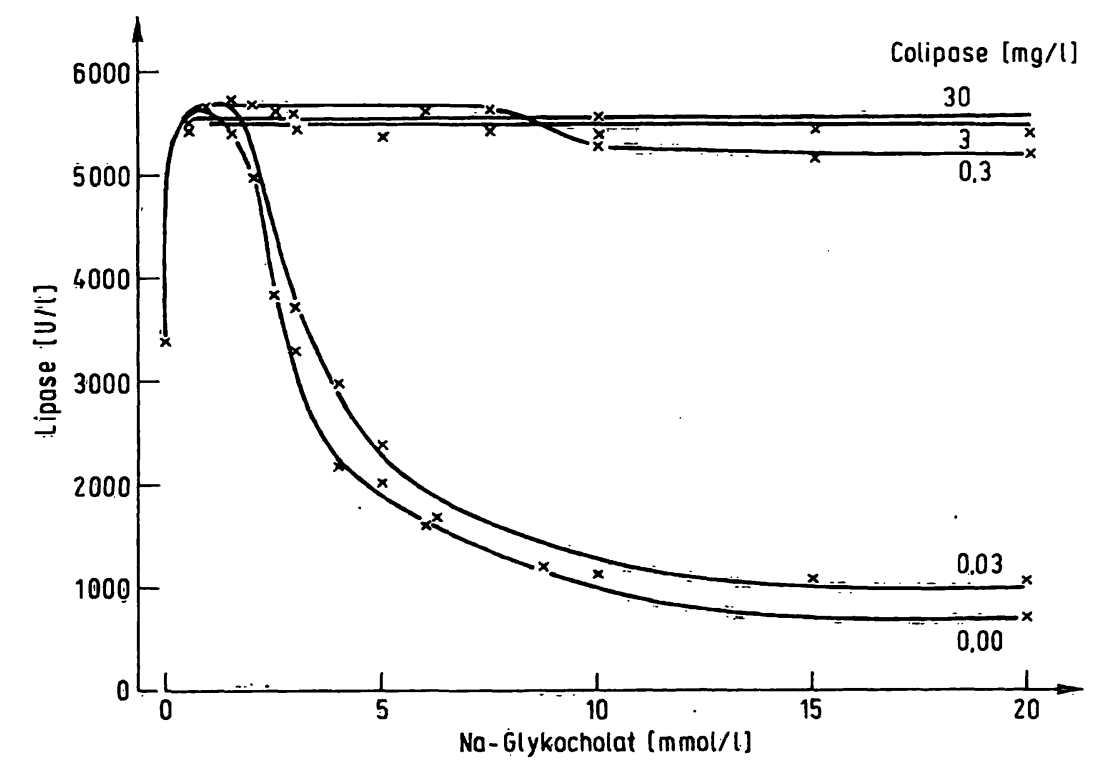

Abb. 9. Kontinuiẹlicher titrimetrischer Test mit Trịolein als Substrat. Abhängigkeit der katalytischen Aktivität von der Konzentriation an Na-Glykocholaț und an Colipase. $100 \mu$ i Serúm H. (seit 1966 eingefroren) im Test.

Aktivierungseffekt von Colipase bei Einsatz von geringen Probevolumina in Abwesenheit von Na-Glykocholat

Wie bereits beschrieben (7), kommt es bei Einsatz sehr geringer Serummengen in den Testansatz (unter $100 \mu$ ) in Abwesenheit von Gallensäuren durch Zusatz von inaktiviertem. Serum oder Humanalbuminlösung zu einer Steigerung des Substratumsatzes. Wir fanden, daß dieser Effekt, wenn kein Glykocholat im Ansatz vorhanden ist, auch durch Colipase bewirkt werden kann. Die Ergeb- nisse sind in Tabelle 3 zusammengestellt: Setzt man 20-100 $\mu \mathrm{l}$ eines Serums mit hoher katalytischer Aktivität in den Test ein, so führt Colipase in einer Endkonzentration von $0,3-3,0 \mathrm{mg} / \mathrm{l}$ zu einer Aktivitätserhöhung. Diese ist prozentual um so stärker ausgeprägt, je weniger Serum und je mehr Colipase im Ansatz vorhanden sind. Mit der höchsten geprüften Konzentration an Colipase $(30 \mathrm{mg} / \mathrm{l})$ wird etwa die gleiche Aktivierung beobachtet wie nach Zusatz von $100 \mu$ inaktiviertem 


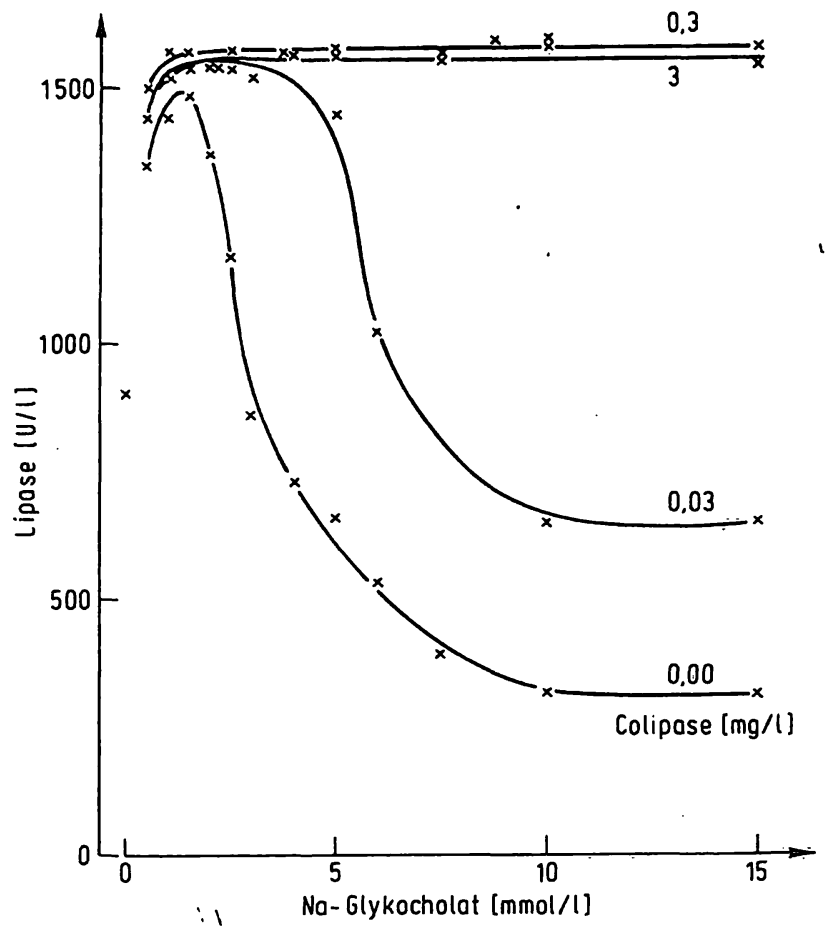

Abb. 10. Kontinuierlicher titrimetrischer Test mit Triolein als Substrat. Abhängigkeit der katalytischen Aktivität von der Konzentration an Na-Glykocholat und an Colipase. $100 \mu 1$ Serum Ä. (nach Entnahme analysiert) im Test.

Sammelserum. Da gegenwärtig keine Methode zur quantitativen Bestimmung der Colipasekonzentration im Serum bekannt ist, kann nicht ausgeschlossen werden, daß das verwendete inaktivierte Serum den Cofaktor enthielt. Unabhängig von der eingesetzten Serummenge

Tab. 3. Kontinuierlicher titrimetrischer Test mit Triolein als Substrat.

Aktivierungseffekt von Colipase bei Einsatz geringer Probevolumina in Abwesenheit von Na-Glykocholat.

\begin{tabular}{|c|c|c|c|c|c|c|}
\hline \multirow[t]{3}{*}{ Zusätze } & \multicolumn{6}{|c|}{ Serum M., Probevolumen im Testansatz } \\
\hline & \multicolumn{2}{|l|}{$100 \mu l$} & \multicolumn{2}{|l|}{$50 \mu 1$} & \multicolumn{2}{|l|}{$20 \mu \mathrm{l}$} \\
\hline & $\begin{array}{l}\bar{x} \\
U / 1\end{array}$ & $\begin{array}{l}\text { rela- } \\
\text { tive } \\
\text { kataly- } \\
\text { tische } \\
\text { Akti- } \\
\text { vität }\end{array}$ & $\begin{array}{l}\bar{x} \\
U / 1\end{array}$ & $\begin{array}{l}\text { rela- } \\
\text { tive } \\
\text { kataly- } \\
\text { tische } \\
\text { Akti- } \\
\text { vität }\end{array}$ & $\begin{array}{l}\bar{x} \\
U / 1\end{array}$ & $\begin{array}{l}\text { rela- } \\
\text { tive } \\
\text { kataly- } \\
\text { tische } \\
\text { Akti- } \\
\text { vität }\end{array}$ \\
\hline \multicolumn{7}{|l|}{ Colipase } \\
\hline $\begin{array}{l}\text { ohne } \\
0,03 \mathrm{mg} / 1 \\
0,3 \mathrm{mg} / 1 \\
3,0 \mathrm{mg} / 1 \\
30,0 \mathrm{mg} / 1\end{array}$ & $\begin{array}{l}3390 \\
3380 \\
3610 \\
4240 \\
4740\end{array}$ & $\begin{array}{l}100 \\
100 \\
106 \\
125 \\
140\end{array}$ & $\begin{array}{l}3150 \\
3530 \\
3840 \\
4230 \\
4560\end{array}$ & $\begin{array}{l}100 \\
112 \\
122 \\
134 \\
145\end{array}$ & $\begin{array}{l}3030 \\
3500 \\
3680 \\
4250 \\
4710\end{array}$ & $\begin{array}{l}100 \\
116 \\
121 \\
140 \\
155\end{array}$ \\
\hline \multicolumn{7}{|c|}{ inaktiviertes Sammelserum } \\
\hline $100 \mu 1 /$ Test & 4630 & 137 & 4380 & 139 & 4350 & 144 \\
\hline \multicolumn{7}{|c|}{ Na-Glykocholat } \\
\hline $0,75 \mathrm{mmol} / \mathrm{l}$ & 6090 & 180 & 6120 & 194 & 6200 & 205 \\
\hline
\end{tabular}

bewirkt der Zusatz von 0,75 mmol/1 Na-Glykocholat in den Test in jedem Fall die höchsten Umsatzgeschwindigkeiten, die nochmals erheblich über denjenigen mit $30 \mathrm{mg} / \mathrm{l}$ Colipase im Test liegen. Ob noch höhere $\mathrm{Co}=$ lipasekonzentrationen in Abwesenheit von Gallensäuren zu einer weiteren Steigerung des Substratumsätzes führen und ob allein durch Colipase die gleichen. Werte wie nach Z̈ugabe von Glykocholat erreicht werden, konnten wir wegen des uns nur begrenzt zur Verfügung stehenden Cofaktors nicht testen. Daß bei zusätzlicher Verwendung von Colipase keine stärkere Aktivierung als durch $0,75 \mathrm{mmol} / 1 \mathrm{Na}-G l y k o c h o l a t$ allein erzielt werden kann, wurde bereits gezeigt (Abb. 7-10).

\section{Postheparinserum im Test}

Wie bereits 1974 beschrieben (14), wird bei der kontinuierlichen titrimetrischen Methode mit Triolein als Sub. strat die katalytische Aktivität der Lipoproteinlipase mitgemessen.

Wie erste Versuche zeigen, könnte der Zusatz von Colipase in den titrimetrischen Test die Möglichkeit eröffnen, die Spezifität des Titrationsverfahrens mit Triolein als Substrat zu erhöhen. In Abbildung 11 sind die Ergebnisse an einem Serum gezeigt, das 10 Minuten nach i.v. Injektion von 5000 I.E. Heparin von einem Gesunden gewonnen wurde. Die vor Injektion von Heparin gegen Triolein gemessene katalytische Aktivität betrug $60 \mathrm{U} / 1$. Sowohl die in diesem Serum enthaltene Pankreaslipase als auch das Postheparinenzym werden durch Glykocholat in einer Endkonzentration von $10 \mathrm{mmol} / 1$ vollständig gehemmt. Setzt man Colipase zu,

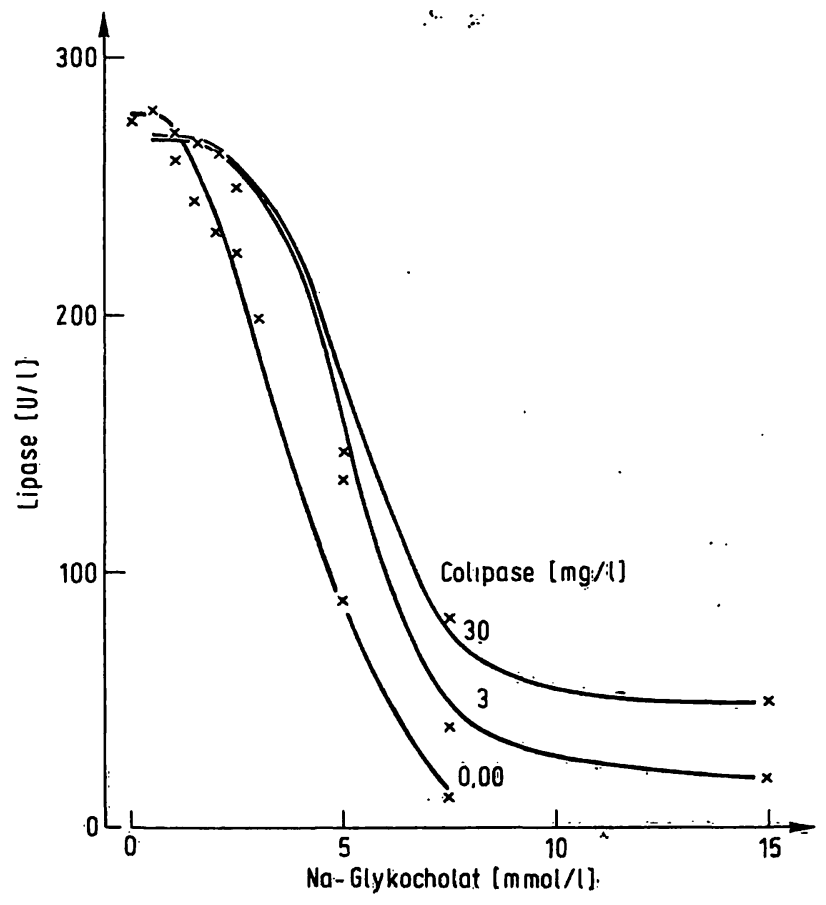

Abb. 11. Kontinuierlicher titrimetrischer Test mit Triolein als Substrat. Abhängigkeit der kataly tischen Aktivität von der Konzentration an Na-Glykocholat und an Colipase. 1,0 ml Postheparinserum im Test. 
so läßt sich eine katalytische Aktivität von etwa $50 \mathrm{U} / 1$ nicht inhibieren; sie dürfte der vorhandenen Pankreaslipase entsprechen. Im Gegensatz dazu wird die aus den Capillarendothelien freigesetzte Lipoproteinlipase nicht durch Colipase vor der Hemmung durch Gallensäuren geschützt.

\section{Diskussion}

Seit 1966 führen wir den kontinuierlichen titrimetrischen Test zur Bestimmung der Lipase im Serum nach dem gleichen Prinzip durch. Lediglich 1969 ersetzten wir das bis dahin als Substrat benutzte Olivenöl durch das besser definierte Triolein. Aufgrund einer veränderten Reagentienqualität wurde es 1980 notwendig, bei der verwendeten Charge (s.o.) die Endkonzentration des Glykocholats auf $0,75 \mathrm{mmol} / 1 \mathrm{zu}$ vermindern. Die Brauchbarkeit des Analysenprinzips wurde auch von Tietz \& Repique (15) gezeigt, die bei $30^{\circ} \mathrm{C}$ arbeiteten, im übrigen aber mit der gleichen apparativen Ausrüstung zu vergleichbaren Ergebnissen hinsichtlich Substrataffinität, pH-Optimum, Hemmung durch Calciumionen u.a. kamen.

\section{Einfluß der Qualität der Reagentien}

Wenn bei Anwendung des kontinuierlichen titrimetrischen Tests Probleme oder widersprüchliche Ergebnisse auftreten, so liegt dies vermutlich in erster Linie an der Qualität der verwendeten Reagentien. Unsere Erfahrungen hierzu sind oben beschrieben. Das größte Problem stellt die Reinheit von Glykocholsäure dar. Ähnliches berichten Kreutzer et al. (16), die 5 von 7 Chargen Desoxycholat unbrauchbar fànden. Wie gezeigt (Tab. 1), tritt der Hemmeffekt durch hohe Glykocholatmengen bei der einz̃elnen Serumprobe in Gegenwạt ganz unterschiedlicher Konzentrationen an Gallensalz auf. Außerdem ist dieser hemmende Einfluß zusätzlich vom eingesetzten Probevolumen im Test abhängig (Abb. 3). Anhand von eingehènden Untersuchungen an verschiedenen Proben mit unterschiedlich hoher katalytischer Aktivität an Lipase gelingt es, das relàtiv schmale Plateau der optimalen Na-Glyköchölatkonzentration für jede Charge und alle Probevolumina festzulegen. Nur unter diesen optimalen Bedingungen verhält sich der Substratumsatz proportional zur eingesetzten Enzymmenge. Liegt die gewählte Gallensäurekonzentration zu niedrig, wird vor allem bei Einsatz kleiner Probevolumina eine zu geringe kataly tische Aktivität gefunden; umgekehrt kommt es mit großen Probevolumina im Test bei zu hoher Glykocholatkonzentration zụ einer Hemmung des Enzyms.

Da von einem klinisch-chemischen Routinelaboratorium nicht erwartet werden kann, sämtliche benutzten Reagentien bezüglich ihrer Reinheit zu charakterisieren und gegebenenfalls - evtl. mehrfach - umzukristallisieren, muß an die Hersteller die Forderung gerichtet werden, Chemikalien in einer für den betreffenden Zweck ausreichenden Reinheit anzubieten. So lange diese Vorausset- zung nicht erfullt ist, kann das Ziel einer Normung - in verschie denen Laboratorien vergleichbare Ergebnisse zu gewährleisten - nicht erreicht werden.

\section{Einfluß der Zusammensetzung der Probe}

Die Diskrepanzen in Arbeiten zur Lipase sind auch dadurch zu erklären, daß die mit gereinigten Enzympräparationen ermittelten Daten und Testbedingungen ohne Kontrolluntersuchungen auf eigenes Versuchsmaterial ganz anderer Zusammensetzung übertragen werden. Es sei hier nochmals betont, daß gerade bei der Bestimmung der Lipase das Probematerial im Testansatz die Ergebnisse entscheidend beeinflußt. Sicher wird häufig mit Probenmischungen gearbeitet, da Patientenmaterial nur begrenzt zur Verfügung steht, oder es wird nur ein bestimmtes Serum eingesetzt. Bei Sekreten oder gereinigten Präparaten sind Haltbarkeit oder Veränderungen durch Lagerung nicht ausreichend bekannt. Auch wird im Einzelfall der Einfluß von Medikamenten nicht ausreichend berücksichtigt, z.B. die Verunreinigung von Duodenalsaft mit wasserlöslichen Röntgenkontrastmitteln oder durch Gallensäuren. Ein Beispiel für eine unkritische Übernahme von Daten ist auch die häufig zitierte, von Henry 1958 (17) beschriebene Interferenz durch Hämolyse. Bei der von ihm verwendeten Methodik ist es unschwer vorstellbar, daß durch hohe Hämoglobinkonzentrationen im Test der Umschlag des Indikators nicht mehr ausreichend sicher zu erkennen ist. In vielen nachfolgenden Arbeiten, denen ganz andere Bestimmungsverfahren zugrunde liegen, findet sich ebenfalls der Hinweis auf Störung bei Einsatz hämolytischer Proben, ohne daß dies durch eigene Versuche untermauert wird. Um bezüglich dieser Frage eine Klärung herbeizuführen, sind die von uns an zwei Seren nach Zugabe von Hämolysat ermittelten Ergebnisse aufgefựrt. Selbst extrem hohe Hämoglobinkonzentrationen im Test hëmmen die Lipase nịcht. Dies wurde auch von Kreutzer et al. (16) gefunden. Da gegen die Versuchsanordnung - den Zusatz von serumfreien Hämolysat zurecht Einwände erhoben werden könnten, sei hier noch erwähnt, daß wir an etwa 20 Proben, bei denen uns Serum ohne und mit deutlich sichtbarer Hämolyse zur Verfügung stand, innerhalb des Meßfehlers gleiche Ergebnisse ermittelten.

\section{Einfluß von Meß- und Regelgeräten}

Auch die verwendeten Geräte sind entscheidend für die Qualität der erhobenen Befunde. Wenn eine Meßanordnung nicht erlaubt, pH-Differenzen um 0,001 zu messen und zu regeln, dann ist sie für die Messung der Lipase im Serum nicht geeignet. Uns liegen nur eigene Erfahrungen mit Titrationsausriustungen der Firma Radiometer vor. Vergleicht man die Angaben zur Charakterisierung der Meßgeräte verschiedener Firmen, so stellt man fest, daß es bisher keine anderen Meßanordnungen gibt, die die erwähnte Empfindlichkeit und Regelgenauigkeit garantieren. Wenn für die Lipaseaktivität nur diskrete Werte angegeben werden: z.B. 16, 32, 48, 95 (ähnlich 96), 
111 (ähnlich 112) (18), so ist anzunehmen, daß das Auflösungsvermögen der verwendeten Meßgeräte unzureichend ist.

\section{Einfluß der Arbeitsweise}

Auch die mangelhafte technische Ausführung und die Kritiklosigkeit bei der Auswertung von Registrierungen sind entscheidend an der unzureichenden Reproduzierbarkeit und den zahllosen gegensätzlichen Aussagen in Bezug auf die Messung der Lipase beteiligt.

Das hier beschriebene kontinuierliche titrimetrische Verfahren erfordert eine Größenordnung mehr KnowHow als z. B. Untersuchungen zum Säure-Basen-Haushalt nach der $A$ strup-Methode mit Äquilibrierung. Man kann zweifellos sagen, daß nicht jede Assistentin in der Lage ist, die Methode zu erlemen. Es sollte aber auch daran gedacht werden, daß der Umgang mit Titrationsanlagen und Elektroden nicht in wenigen Tagen erlernbar ist, sondern daß eine ausreichend lange Einarbeitungszeit, wie sie in der Blutgruppenserologie, Immunologie oder Morphologie selbstverständlich ist, gewährleistet sein muß, bevor reproduzierbare Ergebnisse erwartet werden können. Ein Problem stellt nach wie vor bei Titrationsverfahren im Mikroliterbereich die Diffusion von Flüssigkeit in die Bürettenspitze dar. Wenn über einen unzureichend linearen Substratumsatz berichtet wird, sollte daher zunächst geprüft werden, ob nicht infolge von Arbeitsunterbrechungen die Bürettenspitze mit Flüssigkeit aus dem Ansatz, Pufferlösung, bidest. Wasser 0. ä. verunreinigt ist.

Häufig werden in Publikationen Abbildungen gezeigt, bei denen unmittelbar nach Zugabe von Enzym mit der Registrierung der „Aktivität" begonnen wird. Daß der zunächst ermittelte Laugeverbrauch im Einzelfall nichts mit der tatsächlichen katalytischen Aktivität zu tun hat, dürfte einleuchtend sein, wenn man bedenkt, wie unterschiedlich der pH-Wert der Proben ist; daß er auf 3 Nachkommastellen genau dem gewählten pH-Optimum entspricht, ist ganz unwahrscheinlich. Bei der enormen Tröpfchenzahl im Substrat bedarf es auch bei Abwesenheit von Enzym einer relativ langen Zeit, bis eine $\mathrm{pH}$ Differenz ausgeglichen ist und wieder eine konstante Anzeige nachweisbar wird. Da in Abhängigkeit von der eingesetzten Probenart und -menge über einen langen Zeitraum ein geradliniger Substratumsatz erfolgt, kann nach Start der Reaktion in Ruhe abgewartet werden, bis der Titrator gleichmäßig regelt.

Erstaunlich ist auch, wie großzügig oft die Auswertung der Registrierstreifen erfolgt. Mit dicken Bleistiftstrichen wird der Laugeverbrauch pro Minute „abgeschätzt“, andererseits werden die Ergebnisse mit Nachkommastellen angegeben oder Unterschiede um 10\% als Hemmung oder Aktivierung interpretiert. Durch Parallelverschieben und sorgfältiges Einzeichnen der Steigung sowie durch Ermittlung des Laugeverbrauchs über 5 oder 10 Minuten (je nach katalytischer Aktivität) kann der Fehler durch die Auswertung außerordentlich klein gehalten werden.
Von Bedeutung ist schließlich, daß die Meßbedingungen nicht bei laufender Messung geändert werden können. So dürfen z.B., wie auch schon von Tietz \& Repique (15) beschrieben, Gallensalze nicht nachträglich zugesetzt bzw. ihre Konzentration im gleichen Test nicht schrittweise erhöht werden. Die Ursache ist unklar, vermutlich spielt die Oberflächenwirkung eine entscheidende Rolle.

\section{Vergleich mit diskontinuierlichen Verfahren zur Bestimmung der Ĺipase}

Ein besonders wichtiges Kn̈iterium für eine Methode zur quantitativen Bestimmung der katalytischen Aktivität eines Enzyms stellt die Abhängigkeit des gemessenen Substratumsatzes vơn der eingesetzten Menge Enzym bzw. Probe dar; diese Grundvoraussetzung wurde sowiohl 1969 (7) wie auch seither an hunderten von Proben und von Tietz \& Repique (15) erfüllt, nicht jedoch mit den Zweipunktmethoden. Die Ữrsache für Abweịchungen bei den entsprechenden Verfahren (die Inkubationszeiten sind jeweils in Klammern angegeben) von Cherry \& Crandall, 1932 (19) (24 h), Henry, 1958 (17) (16 h), McDonald \& LeFave, 1962 (20) (3 h), Roe \& Byler, 1963 (21) (1 h), Weber, 1965 (22) (4 h), Tietz \& Fiereck, 1966 (23) (3 h), Tietz \& Fiereck, 1972 (24) (3 h) und Connon et al., 1978 (25) ( $2 \mathrm{~h}$ ) liegt darin, dạß durch die ungewöhnlich langen Inkubationszeiten nicht die Anfangsgeschwindigkeit der enzymatischen Hydrolyse des Substrats gemessen wird. Außerdem kommit es bei höheren katalytischen Aktivitäten während der Inkubation zu einem pH-Abfall, da die Ansätze meist nur schwach gepuffert werden; höhere Konzentrationen der Puffersubstanzen würden, da der Puffer ja mittitriert werden muß, noch höhere Leerwerte ergeben und somit würde das Signal-Rausch-Verhältnis żu Ungunsten des Signals verändert.

Ëbenso muß es z.B. zu denken geben, wenn von Wẹber (22) der Referenzbereich für Lipase mit 20-136 U/1 angegeben wird, andererseits bei Verdünnen eines Serums mit hoher kataly tischer Aktivität (etwa $6500 \mathrm{U} / \mathrm{I}$ ) mit Serum eines Gesunden im Verhältnis 1/6-6/6 Pank reatitisserum Ergebnisse gefunden werden, die im Koordinatennetz durch eine Gerade verbunden werden, die durch den Nullpunkt verlạ̈uft. Wenn diese Darstellung richtig ist, muß dàraus geschlossen werden, daß kataly tísche Aktivitäten im Referenzbereich nicht von Null unterschieden werden können.

Aus den genannten Gründen sind Vergleichsuntersuchungen von Zweipunktverfahren mit dem kontinuierlichen titrimetrischen Test sinnlos, da sich zwangsläufig signifikante Ünterschiede ergeben müssen.

\section{Modifikationen des kontinuierlichen titrimetrischen Tests}

Widersprüchliche Ergebnisse beruhen sicher z.T. auch darauf, daß in der Literatur publizierțe Modifikationen 
angewandt oder selbst Veränderungen des Testansatzes vorgenommen werden, ohne daß in ausreichendem Umfang geprüft wird, welche Konsequenzen diese Variationen für die Erstellung von Befunden an der individuellen Serumprobe haben.

Goebell et al. (26) beschrieben 1968, daß Na-Taurocholat „nicht zu einer wesentlichen Aktivitätssteigerung“ führe. Die Autoren setzten dem Testansatz daher keine Gallensäure zu. Mitteilungen über den Zusammenhang zwischen Probevolumen und gemessener katalytischer Aktivität fehlen jedoch. Eigene Versuche mit Taurocholat zeigten - je nach verwendetem Präparat - einen ähnlichen Zusammenhang $\mathrm{zwischen} \mathrm{prozentualer} \mathrm{Ak-}$ tivitätssteigerung und Probevolumen im Test wie bei Einsatz von Glykocholsäure (Aktivierung bei $20 \mu \mathrm{l}$ Serum etwa $100 \%$, bei $1,0 \mathrm{ml}$ Serum um $15 \%$ ). In Abwesenheit von Gallensäuren wird somit bei niedrigem Probevolumen nicht der maximal mögliche Substratumsatz erreicht und Verdünnungen über einen weiten Bereich ergeben daher keine geradlinige Beziehung zum Ausmaß der Verdünnung.

Andererseits verwenden Tietz \& Repique (15) NaGlykocholat in einer Endkonzentration von $2,0 \mathrm{mmol} / \mathrm{l}$. Es ist durchaus möglich, daß die benutzte Charge Glykocholsäure sich von den von uns verwendeten Präparaten in ihrer Reinheit unterschied, so daß von den Autoren höhere Gallensäurekonzentrationen eingesetzt werden konnten. Da jedoch Hinweise über Ausmaß von Aktivierung und Hemmung durch Glykocholat bei verschiedenen Seren und Probevolumina ausstehen, wäre es auch denkbar, daß die Ergebnisse zufällig an einer Probe gewonnen wurden, bei der die hemmende Wirkung relativ spät auftrat (s. hierzu Tab. 1). Für diese Annahme spricht, daß Tietz \& Repique (15) einen geradlinigen Zusammenhang zwischen gemessener katalytischer Aktivität und eingèsetztem Probevolumen nự bis zu $0,5 \mathrm{ml}$ Serum angeben. Bei Einsatz von $1,0 \mathrm{ml}$ Serum in einem Endvolumen von $15 \mathrm{ml}$ und $2 \mathrm{mmol} / 1 \mathrm{Na}-G l y k o c h o l a t$ fanden auch wir mit allen bisher verwendeten Chargen Glykocholsäure bei der überwiegenden Zahl der untersuchten Proben bereits eine verminderte katalytische Aktivität, während bei $0,5 \mathrm{ml}$ Serụm im Test diese Gallensäurekonzentration meist noch akzeptabel war.

Da der beschriebene titrimetrische Test einen erheblichen experimentellen Aufwand erfordèrt - Titration - mit $10 \mathrm{mmol} / 1 \mathrm{NaOH}$, die unter $\mathrm{CO}_{2}$-Abschluß gehalten werden muß, Rühren des Testansatzes mit $\mathbf{N}_{2}$, damit nicht das $\mathrm{CO}_{2}$ der Raumluft mittitriert wird, Entfettung der Elektroden usw. - , ist es verständlich, daß häufig der Wuńsch nach Vereinfachung entstand. Es muß aber hier ganz klar gesagt werden, daß mit allen bisher beschriebenen Abweichungen vom Testverfahren keine reproduzierbaren Ergebnisse erzielt werden können. Auch hierzu einige Beispiele:

Bei der von uns beschriebenen Methode beträgt der Laugeverbrauch bei einer im Referenzbereich liegenden katalytischen Aktivität von $100 \mathrm{U} / 1$ 4\% der Bürettenfullung pro Minute, d.h. $10 \mu$ einer $10 \mathrm{mmol} / \mathrm{l} \mathrm{Na}$ tronlauge pro Minute. Appel \& Scholz (27) reduzieren das Probevolumen auf $200 \mu \mathrm{l}$ und erhalten dadurch nur noch $1 / 5$ des Signals, der Laugeverbrauch beträgt bei der gleichen katalytischen Aktivität nur $2 \mu \mathrm{l} / \mathrm{min}$. Außerdem wird nicht mit $\mathrm{N}_{2}$ als Schutzgas gearbeitet und die enzymatische Reaktion läuft nicht im $\mathrm{pH}-\mathrm{Op}$ timum, sondern bei pH 8,2 ab. Als Nachweisgrenze geben die Autoren $5 \mathrm{U} / 1$ an. Der Verbrauch an $10 \mathrm{mmol} / \mathrm{l}$ $\mathrm{NaOH}$ beträgt bei dieser ,Aktivität" $0,1 \mu \mathrm{l} / \mathrm{min}$. $\mathrm{Da}$ außerdem aufgrund der Arbeit ohne $\mathrm{N}_{2}$ ein Leerwert zu berücksichtigen ist, scheint es außerordentlich zweifelhaft, ob die angegebenen $5 \mathrm{U} / 1$ noch meßbar sind. Angaben über die Höhe der Leerwerte werden nicht gemacht, so daß die übliche Berechnung der Nachweisgrenze (28) nicht anwendbar ist. Unklar bleibt auch, wie es den Autoren möglich war, mit einem Probevolumen von $500 \mu \mathrm{l}$ - dies entspricht einem Einsatz von $3,0 \mathrm{ml}$ Serum in unseren Test - noch eine geradlinige Beziehung zwischen gemessener katalytischer Aktivität und Probevolumen zu erzielen. Mit mehr als $1,5 \mathrm{ml} \mathrm{Se}$ rum in einem Endvolumen von $15 \mathrm{ml}$ konnten wir diesen Zusammenhang nicht nachweisen.

Aus den genannten Gründen ist es verständlich, daß bei Untersuchung von Kontrollseren mit katalytischer Aktivität ịm Referenzbereich für die Präzision von Tag zu Tag Variationskoeffizienten zwischen 20 und 44\% gefunden werden (27). Bei einem Sollwert von $112 \mathrm{U} / 1$ wurde z.B. ein VK von $30 \%$ ermittelt; dies bedeutet, daß 95\% aller Werte zwischen 46 und $178 \mathrm{U} / 1$ liegen. Vielleicht ist diese erhebliche Streuung auch dafür verantwortlich, daß die Autoren ,methodisch einwandfrei abgesichert geringe katalytische Konzentrationen von Lipase, bis zu 1000 U/1“ im Urin nachweisen konnten.

\section{Fehlinterpretation von publizierten Ergebnissen}

Ein wichtiges Problem ist sicher auch die Interpretation von Literaturangaben durch den flüchtigen Leser. Hierzu sei lediglich im Zusammenhang mit der Frage, ob Colipase einen aktivierenden Effekt auf Pankreaslipase ausübt, auf eine Arbeit von Borgström et al. (29) verwiesen, in der der Einfluß von Rinderserumalbumin, Colipase und Taurodesoxycholat auf die katalytische Aktivität von Lipase aus Schweinepankreas mitgeteilt wird. Ohne Colipase und Gallensalz im Test kommt es bereits bei niedriger Konzentration an Rinderserumalbumin zu einer starken Hemmung der Lipase. Bei Zusatz von Colipase $(0,1 \mathrm{mg} / \mathrm{l})$ zeigt der Fremdprotein-freie Ansatz eine um ca. $40 \%$ höhere Aktivität. Dies entspricht den von uns an Testansätzen mit geringen Serumvolumina gewonnenen Ergebnissen (s. Tab. 3). Durch steigende Albuminkonzentrationen kommt es ebenfalls zu einer Hemmung des Enzyms. Werden Colipase und $4 \mathrm{mmol} / \mathrm{l}$ Taurodesoxycholat in den Ansatz gegeben, entspricht die gemessene katalytische Aktivität bei Abwesenheit von Rinderserumalbumin derjenigen des Colipase-freien 
Ansatzes. Steigende Proteinkonzentrationen im Test führen nicht zu einer Aktivitätsänderung. Aus der Arbeit ist der Schluß gezogen worden, daß Zusatz von Gallensäuren zu Colipase-haltigen Ansätzen die katalytische Aktivität des Enzyms vermindert. Dies ist nicht gerechtfertigt, da Taurodesoxycholat nur in einer Konzentration eingesetzt wurde. Es ist nicht gesichert, ob der Hemmeffekt auf Lipase bei der relativ hohen Gallensäurekonzentration im Test durch den geringen Zusatz von Colipase in seiner Wirkung vollständig aufgehoben wird (s. hierzu Abb. 7). Um Mißverständnissen vorzubeugen, sei darauf hingewiesen, daß die Untersuchungen von Borgström et al. (29) nicht zur Ausarbeitung optimaler Bedingungen für die Bestimmung der Lipase im Serum dienten.

\section{Zusatz von Colipase in den kontinuierlichen titrimetri- schen Test}

Erste Versuche zeigten, daß bei der Messung der Lipase im Serum durch Zusatz von Colipase in Anwesenheit von Na-Glykocholat in optimaler Konzentration kein höherer Substratumsatz zu beobachten ist. Wie in Abbildung 7-10 dargestellt, wird jedoch durch Zusatz von Colipase das Optimum der katalytischen Aktivität von Lipase in Abhängigkeit von der Gallensäurekonzentration verbreitert. Kleine Änderungen in der Zusammensetzung der Glykocholsäure würden somit die katalytische Aktivität nicht mehr so stark beeinflussen. Das Problem der Reinheit von Gallensäuren wird damit aber nicht gelöst, sondern nur verdeckt.

Wie erste Untersuchungen mit Postheparinserum ergaben (Abb. 11), kann dem Testansatz in Anwesenheit von Colipase eine so hohe Konzentration an Glykocholat zugesetzt werden, daß die Lipoproteinlipase weitgehend gehemmt wird; somit ergibt sich ein Ansatz zur Erhöhung der Spezifität des titrimetrischen Tests. Allerdings ist eine solche höhere Spezifität nur in sehr wenigen Fällen von Bedeutung. Bei akuter Pankreatitis liegt die Indikation zur Gabe von Heparin nur dann vor, wenn eine Verbrauchskoagulopathie besteht. Außerdem ist in diesen Fällen die katalytische Aktivität so stark erhöht (wir fanden im Mittel bei Patienten mit akuter Pankreatitis 4920 U/1 (30)), daß die geringgradige Steigerung der Lipolyse um etwa 200-400 U/1 diagnostisch kaum eine Rolle spielt. Da Heparin in der Probe eine Reihe von Analysenverfahren stört, ist es ohnehin notwendig, dem untersuchenden Laboratorium eine entsprechende Medikation mitzuteilen, so daß Fehlinterpretationen vermieden werden. Wenn die Spezifität des kontinuierlichen titrimetrischen Tests durch Zusatz von Colipase erhöht werden soll, müssen die Bedingungen so gewählt werden, daß die Lipoproteinlipase vollständig, die Pankreaslipase jedoch gar nicht gehemmt wird. Da in ersten Versuchen jedes Serum auch bezüglich der zur Aufhebung des Gallensäure-Hemmeffekts notwendigen Colipasekonzentrationen ein individuelles Verhalten zeigte (Abb. 7-10), müßten Unter- suchungen an zahlreichen Seren von Patienten mit einer katalytischen Aktivität an Lipase um $500 \mathrm{U} / 1$, die den Einsatz von 1,0 ml Serum erlaubt, vorgenommen werden, und zwar jeweils vor und nach einer medizinisch indizierten i.v. Verabreichung von Heparin.

Die Beantwortung der Frage, ob dem 'Testsystem Colipase zugesetzt werden soll, ist davon abhängig, ob es möglich ist, Gallensäuren (s.o.) und Colipase mit reproduzierbarer Zusammensetzung bzw. Aktivität allgemein verfügbar $\mathrm{zu}$ machen.

Wenn Glykocholsäure von ausreichender Rèinheit verwendet wird und die Probe keine Lipoproteinlipase enthält, ist ein Zusatz von Colipase zur Bestimmung der Lipase des Serums entbehrlich, da hierdurch von uns bisher in keinem Fall eine Steigerung der kätalytischen Aktivität beobachtet wurde. Weitere Untersuchungen hierzu sind in Gang.

Auch für die Versuche, die Spezifität des Verfahrens für Pankreaslipase zu erhööhen, ist die konstante Qualität der Gallensäure von ausschlāggebender Bedeutung. Nur unter diesen Voraussetžungen sind Arbeiten bezüglich dieses Problems sinnvoll.

Bisher war es möglich, neben Seren gereinigte Lipase, Säulenfraktionen, Sekrete u.a. unter den gleichen Testbedingungen $\mathrm{zu}$ analysieren. Wegen der unżureichenden Kenntnis des äußerst komplizierten Zusammenwirkens von Enzym, Proteinen, Gallensäuren und Cofaktor an den Phasengrenzflächen müssen die Testbedingungen für diese Untersuchungsmaterialien neu überarbèitet werden. Von den Ergebnissen werden wir es abhängig machen, ob oder in welcher Konzentration Colipase eingesetzt werden soll.

\section{Danksagung}

Wir danken Herrn Prof. Dr. H. U. Bergmeyer und Herrn Dr. J. Żiegenhorn für die freundliche Überlassung von Colipase.

\section{Addendum $^{1}$ )}

Kürzlich wurde mitgeteilt, dàß „Bestimmungen von Lipase im Serum nur dann exakte. Werte ergeben, wenn sie in Gegenwart von Colipase durchgeführt werden " (Junge, W. \& Leybold, K. (1982) J. Clin. Chem. Clin. Biochem. 20, 676). Bei der Bewertung dieser Feststellung ist zu berücksichtigen, daß die zugrunde liegenden Ergebnisse nicht - wie angegeben - mit der 1969 (1.c. (7)) bzw. 1976 (1.c. (8)) von uns beśchriebenen Methode, sondern mit der Modifikation von Appel \& Scholz (1.c. (27)) ausgeführt wurden (Diskussion dieser Modifikation s.o.). Der verwendete Testansatz enthielt außerdem Glykocholat in einer Endkonzentration von 1,5 mmöl/l, obwohl einer der Autoren (W. J.) bereits im Juni 1980 von uns in mehreren persönlichen Gesprächen dạüber informiert wurde, daß diese Kon-

\footnotetext{
1) Nach Fahnenkorrektur eingegangen ami15. Oktober 1982 .
} 
zentration bei Verwendung der seit 1979 erhältlichen Chargen deutlich hemmt. Das Auftreten nichtlinearer Zeit-Umsatz-Kurven wird - wenn eine fehlerhafte technische Ausführung ausgeschlossen ist - nur unter folgenden Versuchsbedingungen beobachtet:

1. Die Endkonzentration an Glykocholat im Testansatz liegt zu hoch.

2. In Gallensäure-freie Testansätze wird Untersuchungsmaterial mit außerordentlich geringer Proteinkonzentration (z.B. stark verdünnter Duodenalsaft oder gereinigte Pankreaslipase) eingesetzt. Bei derartigen Untersuchungen wird aber bereits in Anwesenheit von $0,1 \mathrm{mmol} / 1$ Glykocholat ein geradliniger Substratumsatz erreicht.
Auch für die 1981 (Junge, W. \& Leybold, K. (1981) J. Clin. Chem. Clin. Biochem. 19, 225) beschriebenen, systematisch niedrigeren titrimetrisch gemessenen katalytischen Aktivitäten der Lipase im Serum im Vergleich zur sogenannten Turbidimetrie sind die oben diskutierten Probleme in Betracht zu ziehen. Dabei ist zu berücksichtigen, daß das 1976 (1.c. (8)) von uns angegebene Verfahren ohne Modifikation und ohne Zusatz von Colipase als Referenzmethode zur Ermittlung der katalytischen Aktivität des Lipasestandards dient, über den die Ergebnisse der Messungen mit dem sogenannten , turbidimetrischen Test berechnet werden $(Z w e z, W$., pers. Mitteilung 1981).

\section{Literatur}

1. Brockerhoff, H. \& Jensen, R. G. (1974) Lipolytic enzymes. Academic Press, New York.

2. Verger, R. \& Haas, G. H. de (1976) Ann. Rev. Biophys. Bioeng. 5, 77-117.

3. Semeriva, M. \& Desnuelle, P. (1979) Adv. Enzymol. 48, 319-370.

4. Borgström, B., Erlanison-Albertsson, Ch. \& Wieloch, T. (1979) J. Lipid Res. 20, 805-816.

5. Leger, C. \& Charles, M. (1980) Wld. Rev. Nutr. Diet. 35, 96-128.

6. Jung, H., Mitteilung an den Arbeitsausschuß ,Spezielle Methodologie" im Fachnormenausschuß Medizin im DIN.

7. Rick, W. (1969) Z. Klin. Chem. Klin. Biochem. 7, 530-539.

8. Rick, W. (1976) Lipase. In: Handbuch der Inneren Medizin (Forell, M. M. ed.). 5. Aufl. Bd. III/6: Pankreas. Springer, Berlin pp. 350-361.

9. Marchis-Mouren, G., Sarda, L. \& Desnuelle, P. (1959) Arch. Biochem. Biophysics 83, 309-319.

10. Hofstee, B. H. J. (1952) Science 116, 329-331.

11. Proelss, H. F. \& Wright, B. W. (1977) Clin. Chem. 23, 522531.

12. Rick, W. \& Hockeborn, M. In Vorbereitung.

13. Rathelot, J., Julien, R., Canioni, P., Coeroli, C. \& Sarda, L. (1975) Biochimie 57, 1117-1122.

14. Fritsch, W.-P. \& Rick, W. (1974) Postheparinlipase. In: Methoden der enzymatischen Analyse (Bergmeyer, $\mathrm{H}$. U. ed.). 3. Aufl. Verlag Chemie, Weinheim pp. 854-861.

15. Tietz, N. W. \& Rẹpique, E. V. (1973) Clin. Chem. 19, $1268-1275$.

16. Kreutzer, H. H., Pènnings, A. W., Punt, J. M. H. M. \& Verduin, P. A. (1975) Clin. Chim. Acta $60,273-279$.
17. Henry, R. J. (1958) Pancreatitis-lipase. In: Standard methods in clinical chemistry (Seligson, D. ed.). Academic Press, New York 2, pp. 86-90.

18. Ziegenhorn, J., Neumann, U., Knitsch, K. W., Zwez, W., Roeder, A. \& Lenz, H. (1980) Medica 1, 919-925.

19. Cherry, I. S. \& Crandall, L. A. (1932) Amer. J. Physiol. $100,266-273$

20. McDonald, R. P. \& LeFave, R. O. (1962) Clin. Chem. 8, 509-519.

21. Roe, J. H. \& Byler, R. E. (1963) Analyt. Biochem. 6, 451460.

22. Weber, H. (1965) Dtsch. Med. Wochenschr. 90, 11701174.

23. Tietz, N. W. \& Fiereck, E. A. (1966) Clin. Chim. Acta 13, $352-358$.

24. Tietz, N. W. \& Fiereck, E. A. (1972) Measurement of lipase activity in serum. In: Standard methods of clinical chemistry (Cooper, G. R. ed.). Academic Press, New York 7, pp. 1931.

25. Connon, R. E., Kley, H. vain \& Knight, W. A. jr. (1978) Dig. Dis. 23, 472-475.

26. Goebell, H., Bode, Ch. \& Lemberg, G. (1968) Verh. Dtsch. Ges. Inn. Med. 74, 233-235.

27. Appel, W. \& Scholz, H.-G. (1977) J. Clin. Chem. Clin. Biochem. 15, 339-343.

28. Büttner, $\dot{H}$. (1973) Präzisierung von Normalwertbereichen. In: Optimierung der Diagnostik (Lang, H., Rick, W. \& Róka, L. ed.). Springer, Berlin, pp. 233-241.

29. Borgström, B. \& Erlanson, Ch. (1978) Gastroenterology 75, $382-386$.

30. Rick, W. (1968) Verh. Dtsch. Ges. Inn. Med. 74, 230-233.
Prof. Dr. W. Rick

Institut für Klinische Chemie und Laboratoriumsdiagnostik der Universität Düsseldorf Moorenstraße 5 D-4000 Düsseldorf 1 
